\title{
Levels of cytokines in the aqueous humor of eyes with primary open angle glaucoma, pseudoexfoliation glaucoma and cataract
}

Nervana Khalef ${ }^{1}$, Hany Labib ${ }^{2}$, Hazem Helmy², Mona Abd El Hamid ${ }^{3}$, Leqaa Moemen ${ }^{3}$, Iman Fahmy²

${ }^{1}$ Clinical Pathology Unit, Research Institute of Ophthalmology, Giza, Egypt

${ }^{2}$ Ophthalmology Department, Research Institute of Ophthalmology, Giza, Egypt

${ }^{3}$ Medical Biochemistry Unit, Research Institute of Ophthalmology, Giza, Egypt

Type of article: Original

\begin{abstract}
Objective: The focus of this study aimed at measuring multiple inflammatory cytokines levels in the aqueous humor of patients with primary open angle glaucoma (POAG), pseudoexfoliation glaucoma (PEXG) and senile cataract.

Methods: This case control study was conducted at the Research Institute of Ophthalmology, Giza, Egypt in 2016. Aqueous humor (AH) samples were withdrawn from 50 patients (30 POAG, and 20 PEXG) and from 15 patients with senile cataract serving as controls. The levels of IL6, IL8, transforming growth factor $\beta 1$ (TGF $\beta 1$ ), tumor necrosis growth factor $\alpha(\mathrm{TNF} \alpha)$ and serum amyloid A (SAA) were analyzed by ELISA immune-assay. Data were analyzed by SPSS 10, using Pearson Product-Moment Correlation and independent-samples t-test.

Results: The levels of IL8, TGF $\beta 1$, TNF $\alpha$ and SAA were significantly higher in POAG and PEXG patients, compared to senile cataract patients. While the levels of IL6, were significantly decreased in both groups of glaucoma patients compared to cataract patients. Significant positive correlations were detected between IL6, IL $8 \&$ TGF $\beta 1$, IL 8 ; SAA, IL8 \& TGF $\beta 1$, SAA in the aqueous humor of different groups.

Conclusion: Thus the assayed cytokines including TGF $\beta 1$, TNF $\alpha$, IL8 and SAA in aqueous humor, play a vital role in IOP elevations in patients with POAG and PEXG.

Keywords: Cytokines, Primary open angle glaucoma, Pseudoexfoliation glaucoma
\end{abstract}

\section{Introduction}

Glaucoma can be identified by the progressive optic neuropathy and loss of visual field, due to elevated intraocular pressure (1). The IOP increases in POAG and PEXG, because of the reduction of aqueous humor outflow at the trabecular meshwork (TM) (2). This happens because of an increase of resistance in the aqueous humor outflow due to changes in the amount and quality of the extracellular matrix in the trabecular meshwork (TM) (3). The primary cause of chronic IOP elevation in PEXG is considered to be an age-related, complex, generalized disorder of extracellular matrix ECM and an accumulation of abnormal fibrillar materials in the TM (4). Various genetic internal and external stress factors such as, immune reactions, inflammations, ischemia, hypoxia and oxidative stress are involved in the pathogenesis of glaucoma (5). A number of cytokines including IL6, IL8, TGF $\beta 1$, TNF $\alpha$ and SAA have been detected in the aqueous humor (6). Changes in ocular inflammatory cytokines expression can be detected as changes in the concentration of the above cytokines if there is association between an immune reaction and/or chronic inflammation at the TM or anterior segment and elevated IOP in POAG or PEXG (7). The aim of this research was to detect the role of different cytokines in the pathogenesis of glaucoma.

\section{Material and Methods}

\subsection{Research design and participants}

This case-control study was conducted in 2016. The study involved 50 patients with glaucoma, 30 patients with POAG and 20 patients with (PEXG) attending glaucoma clinic of the Research Institute of Ophthalmology, Giza,

\section{Corresponding author:}

Professor Dr. Leqaa Moemen, Medical Biochemistry Unit, Research Institute of ophthalmology, Egypt.

Tel: +201001033755, E-Mail: leqaa.moemen@yahoo.com

Received: November 13, 2016, Accepted: January 16, 2017, Published: February 2017

iThenticate screening: January 14, 2017, English editing: January 28, 2017, Quality control: February 04, 2017

(C) 2017 The Authors. This is an open access article under the terms of the Creative Commons Attribution-NonCommercialNoDerivs License, which permits use and distribution in any medium, provided the original work is properly cited, the use is non-commercial and no modifications or adaptations are made. 
Egypt, and 15 patients with senile cataract serving as control subjects. Patients with diabetes mellitus, major systemic illness, myocardial Infarction, hypertension, evidence of renal or hepatic diseases. Also patients with other types of glaucoma were excluded

\subsection{Ethics of research}

A written informed consent for aqueous humor collection were obtained from all patients in this study. This study was approved by the Ethics Committee of the Research Institute of Ophthalmology (Egypt).

\subsection{Examinations}

A detailed medical history was obtained to identify patients with risk factors for vascular disease such as, hypertension, diabetes mellitus, hyperlipidemia, smoking status and also the presence of cardiovascular and cerebrovascular disease. Slit lamp bio-microscopy, best corrected visual acuity, and gonioscopy were carried out in order to evaluate the anterior chamber angle, and the intraocular pressure (IOP) was tested using the Goldman applanation tonometer. Visual field (VF) was determined using the Humphrey automated field analyzer and a fundoscopic examination was carried out using a 90-diopter lens with determination of the $\mathrm{C} / \mathrm{D}$ ratio, optic disc rim, optic disc pallor, lamina cribrosa, blood vessels, hemorrhages and retinal nerve fiber layer defects. Aque ous humor samples $(150 \mu \mathrm{l})$ were carefully collected at the beginning of glaucoma or cataract surgery through a limbal paracentesis using $0.5 \mathrm{ml}$ syringe with 27 -gauge needle on tuberculin syringe under the operating microscope with special care to avoid blood or intraocular tissues contamination. All samples were immediately frozen and stored at $70{ }^{\circ} \mathrm{C}$ until assay was performed. Levels of IL6, IL8, TGF $\beta 1, \mathrm{TNF} \alpha$ and SAA were estimated in aqueous humor using enzyme linked immunosorbent assay kits (ELISA).

\subsection{Data analysis}

Statistical methods: SPSS version 10 (SPSS Inc., Chicago, Illinois, USA) was used for data management and analysis. Data were analyzed using descriptive statistics, Independent-samples t-test, and Pearson Product-Moment Correlation.

\section{Results}

The concentration of the five cytokines analyzed were shown in Table 1. All cytokines were detected in all the tested samples. The levels of IL8, TGF $\beta 1$, TNF $\alpha$ and SAA were significantly higher $(\mathrm{p}<0.001)$ in glaucoma patients compared to senile cataract patients. Also, IL6 was significantly lower in glaucoma patients compared to senile cataract patients $(\mathrm{p}=0.0125)$. The correlation between the cytokines concentration are shown in Table 2 . Significant positive correlations were found between IL6 and IL8 $(\mathrm{p}=0.001)$ IL8 and TGF $\beta 1,(\mathrm{p}<0.0001)$, IL8 and SAA $(\mathrm{p}<0.001)$, TGF $\beta 1$ and SAA $(\mathrm{p}<0.001)$ in the aqueous humor of different groups (Table 2$)$.

Table 1. Demographic Data and Levels of Aqueous Humor IL6, IL8, TGF $\beta 1$, TNF $\alpha$ and SAA assayed in all the Studied Groups (mean \pm SD)

\begin{tabular}{|l|l|l|l|l|}
\hline \multirow{2}{*}{ Variables } & \multicolumn{2}{l|}{ Groups } \\
\cline { 2 - 5 } & Cataract $(\mathrm{n}=15)$ & POAG $(\mathrm{n}=30)$ & PEXG $(\mathrm{n}=20)$ & p-value \\
\hline Age $($ year) $($ Mean \pm SD) & 63 & 65 & 67 & \\
\hline Sex $(\mathrm{Male} /$ Female) & $8 / 7$ & $15 / 20$ & $8 / 12$ & \\
\hline IL6 $(\mathrm{Pg} / \mathrm{ml})$ & $64.3 \pm 22.1$ & $15.1 \pm 1.5$ & $23 \pm 1.4$ & $<0.05$ \\
\hline IL8 $(\mathrm{Pg} / \mathrm{ml})$ & $1.5 \pm 1.2$ & $3.2 \pm 1.9$ & $5.6 \pm 3.6$ & $<0.001$ \\
\hline TGF $\beta 1(\mathrm{Pg} / \mathrm{ml})$ & $5.4 \pm 4.6$ & $26.9 \pm 0$ & $67.7 \pm 58$ & $<0.001$ \\
\hline TNF $\alpha(\mathrm{Pg} / \mathrm{ml})$ & $1.5 \pm 0.7$ & $1.6 \pm 1.2$ & $2.3 \pm 1.7$ & $<0.001$ \\
\hline SAA $(\mathrm{Pg} / \mathrm{ml})$ & $7.2 \pm$ & 85.8 & $132 \pm$ & $<0.001$ \\
\hline
\end{tabular}

Table 2. The Correlations among Cytokines assayed using Pearson Product-Moment Correlation.

\begin{tabular}{|l|l|l|l|l|l|}
\hline $\mathrm{p}$-value & IL6 & IL8 & TGF $\beta 1$ & TNF $\alpha$ & SAA \\
\hline IL6 & - & $0.61 ; \mathrm{p}<0.05$ & - & - & - \\
\hline IL8 & $0.61 ; \mathrm{p}<0.05$ & - & $0.72 ; \mathrm{p}<0.001$ & - & $0.81 ; \mathrm{p}<0.001$ \\
\hline TGF $\beta 1$ & - & $0.72 ; \mathrm{p}<0.001$ & - & - & $0.74 ; \mathrm{p}<0.001$ \\
\hline TNF $\alpha$ & - & - & - & - & - \\
\hline SAA & - & $0.81 ; \mathrm{p}<0.001$ & $0.74 ; \mathrm{p}<0.001$ & - & \\
\hline
\end{tabular}




\section{Discussion}

A potential contributing influence for associated increase of POAG in IOP is the compromised outflow facility of aqueous humor through the TM. An increased accumulation of ECM which occurs in the TM region of POAG eyes is thought to impose greater resistance to the outflow of AH, resulting in increased IOP. (8). Exfoliation syndrome can be characterized by buildup of an abnormal fibrillar ECM material chiefly to the lens, cornea and TM often leading to secondary glaucoma (9). In this study, clear elevation of cytokines including IL8, TGF $\beta 1$ and SAA levels, an immune reaction or inflammation, was detected in glaucoma eyes compared to control eyes. IL8, has a role in chemokine functions, as TM cells could be a local source of IL8 secretion (10). The significant positive correlation between IL8 and IOP seen in the current study suggests the role of IL8 in the positive regulation of outflow resistance (11) despite the molecular mechanism of action of IL8 on the TM remaining unclear. TGF- $\beta 1$ signaling, throughout the body and the eye, acts in various biological processes such as fibrotic responses, ECM turn over, proliferation, apoptosis and modulation of the immune system (12). This study, showed significantly higher levels of TGF $\beta 1$ in aqueous-humor from POAG and PEXG patients compared to cataract patients. Many previous results (13, 14), are in agreement with our result. They postulated that TGF $\beta 1$ cytokine alters the extracellular matrix ECM metabolism and excess ECM has been proposed to increase aqueous outflow resistance in the trabecular meshwork TM of glaucomatous eye. It has been found that in vitro treatment of cultured human TM cells with TGF $\beta 1$ will lead to variations in gene expression, including genes that may contribute to buildup of ECM (15). In addition, a significant positive correlation was found between TGF $\beta 1$ and IL8 in the present study, thus the levels of TGF $\beta 1$ and IL8 may reflect the status of ECM remodeling and the severity of reduction in aqueous humor outflow facility at the TM in eyes with POAG and PEXG (16). This study detected elevations of SAA in aqueous humor samples from the glaucomatous eyes compared to control group. This is in agreement with Takai et al. who found the same results (17). SAA has a significant part to play regarding inflammation, infections, tissue repair and amyloid deposition (18). A pro inflammatory cytokine-induced up-regulation of SAA biosynthesis in the liver (19), macrophages, smooth muscle cells and endothelial cells (20), is the prime mediator in an acute phase response in inflammation. There is uncertainty of the exact source of SAA detection in the aqueous humor, but many cellular signal transduction pathways (21), such as the extracellular-signal regulated kinase P58, mitogen-activated protein kinase and nuclear factor Kappa $\beta$ (NFK $\beta$ ) dependent pathways are activated by SAA (22). This intensifies the production of matrix metalloproteinases, cytokines and cytokine receptor, and brings about the reduction of TNF $\alpha$, ILB1 and IL8 (23). In PEXG, buildup of irregular extracellular material in the trabecular meshwork, whether in the form of plaque material or EXG material, could be the cause of increased outflow resistance and chromic elevation of IOP (24) The amplified aqueous levels of endogenous matrix metalloproteinases 2 (MMP2) activity could be of significance in the abnormal matrix accumulation found in the juxtacanalicular meshwork of PEXG eyes (25). Proinflammatory cytokine IL6 decreased significantly in POAG compared to the control in this study and PEXG patients. TM cells could be a local source of IL6, considering expression of IL6 mRNA in normal donor TM and secretion of IL6 in cultured human TM cells after TGF $\beta 1$ treatment have previously been found. TM cell loss with aging can be accountable for functional pathological change in TM tissues in POAG. Considering IL6 is a vital mediator of increased vascular permeability and endothelial dysfunction (17), increased IL6 could be the reason for iris vasculopathy and breakdown of blood-aqueous barriers that are characteristics of PEXG (17). The present study detected significant increase in TNF $\alpha$ concentration in the aqueous humor sample of both POAG and PEXG, compared to control. TNF $\alpha$ was elevated in the optic nerve and retina of the human glaucomatous cadaver eyes, thus $\mathrm{TNF} \alpha$ may have a vital role in damaging the retinal ganglion cells rather than increased resistance to aqueous outflow in POAG (28). The significant correlation of TGF $\beta 1$, IL8 and SAA levels and the significant correlation of these cytokines and the IOP levels suggested that the cytokine networks play important roles in the IOP elevations in POAG (29). Although the exact mechanism of the interactions among these cytokines are unclear, it was found that adding recombination SAA to cultured TM cells potentially stimulated IL8 secretion (30), thus cytokine like prognostics of SAA may induce an immune reaction - specifically related to IL8 (31). Cross pathways among TGF $\beta 1$, TNF $\alpha$, IL 8 and SAA and the exact source of these cytokines could be targets of future investigations of the pathogenesis of IOP levels in glaucoma.

\section{Acknowledgments:}

The author thanks Research Institute of Ophthalmology, Giza, Egypt, for supporting this research.

\section{Conflict of Interest:}

There is no conflict of interest to be declared. 


\section{Authors' contributions:}

All authors contributed to this project and article equally. All authors read and approved the final manuscript.

\section{References:}

1) Ritch R, Schlötzer-Schrehardt U. Exfoliation Syndrome. Surv Ophthalmol. 2001; 45(4): 265-315. doi: 10.1016/S0039-6257(00)00196-X

2) Schlötzer-Schrehardt U, Naumann GO. Ocular and Systemic Pseudoexfoliation syndrome. Am J Ophthalmol. 2006; 141(5): 921-37. doi: 10.1016/j.ajo.2006.01.047. PMID: 16678509.

3) Grus FH, Joachim SC, Wuenschig D, Rieck J, Pfeiffer N. Autoimmunity and glaucoma. J Glaucoma. 2008; 17(1): 79-84. doi: 10.1097/IJG.0b013e318156a592. PMID: 18303391.

4) Tezel G, Wax MB. The immune system and glaucoma. Curr Opin Ophthalmol. 2004; 15: 80-4. doi: 10.1097/00055735-200404000-00003. PMID: 15021215.

5) Li G, Luna C, Liton PB, Navarro I, Epstein DL, Gonzalez P. Sustained stress response after oxidative stress in trabecular meshwork cell. Mol Vis. 2007; 13: 2282-8. PMID: 18199969, PMCID: PMC3158032.

6) Nakabayashi M. Review of the ischemia hypothesis for ocular hypertension other than congenital glaucoma and closed-angle glaucoma. Ophthalmologica. 2004; 218(5): 344-9. doi: 10.1159/000079477. PMID: 15334016.

7) Yu AL, Fuchshofer R, Kampik A, Welge-Lüssen U. Effects of oxidative stress in trabecular meshwork cells are reduced by prostaglandin analogues. Invest Ophthalmol Vis Sci. 2008; 49(11): 4872-80. doi: 10.1167/iovs.07-0984. PMID: 18971427.

8) Zenkel M, Lewczuk P, Jünemann A, Kruse FE, Naumann GO, Schlötzer-Schrehardt U. Proinflammatory cytokines are involved in the initiation of the abnormal matrix process in pseudoexfoliation syndrome/glaucoma. Am J Pathol. 2010; 176(6): 2868-79. doi: 10.2353/ajpath.2010.090914. PMID: 20395431, PMCID: PMC2877848.

9) Fleenor DL, Shepard AR, Hellberg PE, Jacobson N, Pang IH, Clark AF. TGFbeta2-induced changes in human trabecular meshwork: implications for intraocular pressure. Invest Ophthalmol Vis Sci. 2006; 47(1): 226-34. doi: 10.1167/iovs.05-1060. PMID: 16384967.

10) Kuchtey J, Rezaei KA, Jaru-Ampornpan P, Sternberg P Jr, Kuchtey RW. Multiplex cytokine analysis reveals elevated concentration of interleukin-8 in glaucomatous aqueous humor. Invest Ophthalmol Vis Sci. 2010; 51(12): 6441-7. doi: 10.1167/iovs.10-5216. PMID: 20592224. PMCID: PMC3055764.

11) Luna C, Li G, Liton PB, Qiu J, Epstein DL, Challa P, et al. Resveratrol prevents the expression of glaucoma markers induced by chronic oxidative stress in trabecular meshwork cells. Food Chem Toxicol. 2009; 47(1): 198-204. doi: 10.1016/j.fct.2008.10.029. PMID: 19027816, PMCID: PMC2674270.

12) Gottanka J, Chan D, Eichhorn M, Lütjen-Drecoll E, Ethier CR. Effects of TGF-beta2 in perfused human eyes. Invest Ophthalmol Vis Sci. 2004; 45(1): 153-8. doi: 10.1167/iovs.03-0796. PMID: 14691167.

13) Lütjen-Drecoll E. Morphological changes in glaucomatous eyes and the role of TGFbeta2 for the pathogenesis of the disease. Exp Eye Res. 2005; 81(1): 1-4. doi: 10.1016/j.exer.2005.02.008. PMID: 15978248.

14) Robertson JV, Golesic E, Gauldie J, West-Mays JA. Ocular gene transfer of active TGF-beta induces changes in anterior segment morphology and elevated IOP in rats. Invest Ophthalmol Vis Sci. 2010; 51(1): 308-18. doi: 10.1167/iovs.09-3380. PMID: 19696167.

15) Shifera AS, Trivedi S, Chau P, Bonnemaison LH, Iguchi R, Alvarado JA. Constitutive secretion of chemokines by cultured human trabecular meshwork cells. Exp Eye Res. 2010; 91(1): 42-7. doi: 10.1016/j.exer.2010.04.001. PMID: 20403352.

16) Takai $Y$, Tanito M, Ohira A. Multiplex cytokine analysis of aqueous humor in eyes with primary openangle glaucoma, exfoliation glaucoma, and cataract. Invest Ophthalmol Vis Sci. 2012; 53(1): 241-7. doi: 10.1167/iovs.11-8434. PMID: 22159018.

17) Wang WH, McNatt LG, Pang IH, Hellberg PE, Fingert JH, McCartney MD, et al. Increased expression of serum amyloid A in glaucoma and its effect on intraocular pressure. Invest Ophthalmol Vis Sci. 2008; 49(5): 1916-23. doi: 10.1167/iovs.07-1104. PMID: 18223246.

18) Eckersall PD, Bell R. Acute phase proteins: Biomarkers of infection and inflammation in veterinary medicine. Vet J. 2010; 185(1): 23-7. doi: 10.1016/j.tvj1.2010.04.009. PMID: 20621712.

19) Upragarin N, Landman WJ, Gaastra W, Gruys E. Extrahepatic production of acute phase serum amyloid A. Histol Histopathol. 2005; 20(4): 1295-307. PMID: 16136510.

20) Baranova IN, Vishnyakova TG, Bocharov AV, Kurlander R, Chen Z, Kimelman ML, et al. Serum amyloid A binding to CLA-1 (CD36 and LIMPII analogous-1) mediates serum amyloid A protein-induced 
activation of ERK1/2 and p38 mitogen-activated protein kinases. J Biol Chem. 2005; 280(9): 8031-40. doi: 10.1074/jbc.M405009200. PMID: 15576377.

21) Jijon HB, Madsen KL, Walker JW, Allard B, Jobin C. Serum amyloid A activates NF-kappaB and proinflammatory gene expression in human and murine intestinal epithelial cells. Eur J Immunol. 2005; 35(3): 718-26. doi: 10.1002/eji.200425688. PMID: 15724247.

22) Vallon R, Freuler F, Desta-Tsedu N. Serum amyloid A (apoSAA) expression is up-regulated in rheumatoid arthritis and induces transcription of matrix metalloproteinases. J Immunol. 2001; 166(4): 2801-7. doi: 10.4049/jimmunol.166.4.2801. PMID: 11160347.

23) Furlaneto CJ, Campa A. A novel function of serum amyloid A: a potent stimulus for the release of tumor necrosis factor-alpha, interleukin-1beta, and interleukin-8 by human blood neutrophil. Biochem Biophys Res Commun. 2000; 268(2): 405-8. doi: 10.1006/bbrc.2000.2143. PMID: 10679217.

24) Liton PB, Li G, Luna C, Gonzalez P, Epstein DL. Cross-talk between TGF-betal and IL-6 in human trabecular meshwork cells. Mol Vis. 2009; 15: 326-34. PMID: 19209241, PMCID: PMC2637787.

25) Caballero M, Liton PB, Challa P, Epstein DL, Gonzalez P. Effects of donor age on proteasome activity and senescence in trabecular meshwork cells. Biochem Biophys Res Commun. 2004; 323(3): 1048-54. doi: 10.1016/j.bbrc.2004.08.195. PMID: 15381105.

26) Ribeiro FP, Furlaneto CJ, Hatanaka E, Ribeiro WB, Souza GM, Cassatella MA, et al. mRNA expression and release of interleukin-8 induced by serum amyloid A in neutrophils and monocytes. Mediators Inflamm. 2003; 12(3): 173-8. doi: 10.1080/0962935031000134897. PMID: 12857601, PMCID: PMC1781605.

27) Yuan L, Neufeld AH. Tumor necrosis factor-alpha: a potentially neurodestructive cytokine produced by glia in the human glaucomatous optic nerve head. Glia. 2000; 32(1): 42-50. doi: 10.1002/10981136(200010)32:1<42::AID-GLIA40>3.0.CO;2-3.

28) Tezel G, Li LY, Patil RV, Wax MB. TNF-alpha and TNF-alpha receptor-1 in the retina of normal and glaucomatous eyes. Invest Ophthalmol Vis Sci. 2001; 42(8): 1787-94. PMID: 11431443.

29) Sawada H, Fukuchi T, Tanaka $T$, Abe H. Tumor necrosis factor-alpha concentrations in the aqueous humor of patients with glaucoma. Invest Ophthalmol Vis Sci. 2010; 51(2): 903-6. doi: 10.1167/iovs.09-4247. PMID: 19737888.

30) Wang N, Chintala SK, Fini ME, Schuman JS. Activation of a tissue-specific stress response in the aqueous outflow pathway of the eye defines the glaucoma disease phenotype. Nat Med. 2001; 7(3): 304-9. doi: 10.1038/85446. PMID: 11231628, PMCID: PMC1945815. 